\title{
Bismuth Trioxide Modified Carbon Nanotubes as Negative Electrode Catalysts for all Vanadium Redox Flow Batteries
}

\author{
Youqun Chu*, Haixia Zhou, Huimin Zhao
}

State Key Laboratory Breeding Base of Green Chemistry-Synthesis Technology, Chemical Engineering College, Zhejiang University of Technology, Hangzhou 310014, China

*E-mail: chuyq@zjut.edu.cn

doi: $10.20964 / 2020.08 .34$

Received: 12 March 2020 / Accepted: 24 Maj 2020 / Published: 10 July 2020

Bismuth trioxide modified carbon nanotubes $\left(\mathrm{Bi}_{2} \mathrm{O}_{3} / \mathrm{CNTs}\right)$ composite was fabricated by liquid phase deposition-calcinating method and used as electrocatalyst for $\mathrm{V}^{3+} / \mathrm{V}^{2+}$ redox couple of all vanadium redox flow batteries (VRFBs). The modification of Bi species at the surface of CNTs can significantly inhibit the hydrogen evolution reaction and enhance the electrochemical activity to the $\mathrm{V}^{2+} / \mathrm{V}^{3+}$ redox reaction. The VRFB single cell with $\mathrm{Bi}_{2} \mathrm{O}_{3} / C N T$ s modified graphite felt as negative electrode exhibits excellent energy storage performances, such as higher charge/discharge capacity and energy efficiency, indicating that the $\mathrm{V}^{2+} / \mathrm{V}^{3+}$ redox reaction can be facilitated significantly by $\mathrm{Bi}_{2} \mathrm{O}_{3} / \mathrm{MWCNTs}$ composite.

Keywords: bismuth trioxide; carbon nanotubes; vanadium redox flow batteries; hydrogen evolution overpotential

\section{FULL TEXT}

(C) 2020 The Authors. Published by ESG (www.electrochemsci.org). This article is an open access article distributed under the terms and conditions of the Creative Commons Attribution license (http://creativecommons.org/licenses/by/4.0/). 